\title{
Commentary \\ German Media and Coronavirus: Exceptional Communication-Or Just a Catalyst for Existing Tendencies?
}

\author{
Holger Wormer \\ Department of Science Journalism, Institute and School of Journalism, TU Dortmund University, 44221 Dortmund, \\ Germany; E-Mail: holger.wormer@tu-dortmund.de
}

Submitted: 11 May 2020 | Accepted: 12 May 2020 | Published: 26 June 2020

\begin{abstract}
The Covid-19 pandemic has immediate effects on science journalism and science communication in general, which in a few cases are atypical and likely to disappear again after the crisis. However, from a German perspective, there is some evidence that the crisis-and its accompanying 'infodemic' - has, above all, accelerated and made more visible existing developments and deficits as well as an increased need for funding of science journalism.
\end{abstract}

\section{Keywords}

coronavirus; fake news; journalism funding; science communication; science journalism

Issue

This commentary is part of the issue "Health and Science Controversies in the Digital World: News, Mis/Disinformation and Public Engagement" edited by An Nguyen (Bournemouth University, UK) and Daniel Catalan (University Carlos III of Madrid, Spain).

(C) 2020 by the author; licensee Cogitatio (Lisbon, Portugal). This article is licensed under a Creative Commons Attribution 4.0 International License (CC BY).

\section{Introduction}

"Which virologist do you trust the most?" The fact that scientists can be chosen in a 'Germany's-next-topmodel' manner by a tabloid such as BILD in April 2020 is just one of many curiosities in coronavirus communication. Another is that a public relations (PR) agency has scripted to some extent the field research of one of these virologists (\#heinsbergprotokoll) at the hotspot in the community of Heinsberg, nicknamed "Germany's Wuhan" (Connolly, 2020). More serious but still remarkable is when the radio podcast of another virologist is not only nominated for the Grimme Online Award, for which journalistic quality plays a major role, but also for the Communicator Award of the German Science Foundation. The difference between science journalism and the self-communication of science seems to become increasingly blurred in times of coronavirus. Less curious than paradoxical, finally, is that, at a time when the demand for information in the classic journalistic media is higher than it has been for long, many of these very media are on the verge of ruin, with losses of $80 \%$ on adver- tising. If one wants to interpret such events and developments, one must carefully distinguish between what is due to the current exceptional situation and what is symptomatic of general trends in science communication and the mass media.

\section{The Interaction between Science and Journalism}

It has been more than six years since an intensified discussion about the quality of science communication began in Germany (e.g., acatech - National Academy of Science and Engineering, German National Academy of Sciences Leopoldina, \& Union of the German Academies of Sciences and Humanities, 2017). Since then, there have been repeated calls to strengthen science journalism and to sharpen the distinction between genuine science communication and mere science PR. In recent years, however, there has also been growing pressure on scientists to regard communication with the general public as an additional compulsory task. The demands of the German Federal Ministry of Research are particularly farreaching (and often criticised) in this respect. 
The coronavirus crisis highlights the dilemma that could arise if science journalists' expertise is lost while scientists are overloaded with communication tasks. This problem becomes even more acute in a small field of research as very few experts have specialised in coronaviruses. In the pandemic, these experts are to press ahead with research at full speed on the one hand, but on the other hand they are expected to be available for the media. Science journalists also complain that health authorities and research institutions increasingly tend to channel information through their press offices so strictly that reasonable investigation becomes hardly possible. For example, questions for press conferences have to be sent in days in advance so that journalists have even joked that the way German health authorities carry out press work in those days is almost reminiscent of totalitarian states.

Another well-known phenomenon could be observed particularly vividly in coronavirus time: a convergence of science journalism and self-communication of science (Russ-Mohl, 2012). In this particular case, the publicly funded Norddeutscher Rundfunk produced an almost daily podcast with Christian Drosten, recently featured in Science, and probably the leading coronavirus expert in Germany. Thus, a broad public of a prominent radio station received first-hand, not pressoffice filtered information from a competent scientist. In this respect, considering the exceptional situation, the mentioned double nomination for a Grimme Online Award and the Communicator Award (as a 'special onetime prize') may be justified. However, from the overarching perspective of journalism research, the format may be regarded as another symptom of the described convergence between science journalism and science's self-communication. From a pessimistic point of view, it could even mark the beginning of a relapse into long gone times of 'embedded' science journalism, in which science journalists, instead of persistently inquiring watchdogs, are once again degraded to well-behaved cheerleaders (Rensberger, 2009).

Furthermore, the enormous reach of the podcast should not blur the fact that the format of an expert almost monologuing for 30 to 45 minutes, often without critical questioning of the present journalist, would hardly be suitable for popular science journalism beyond the crisis. It is true that the explanations provided are often helpful for educated listeners, but without the extremely high intrinsic pre-interest in view of the pandemic probably far fewer people would follow. However, even if you do not understand everything these days, listening to a potential rescuer from the threatening virus should make many users feel good. Such an emerging personality cult reminds a little bit of Stephen Hawking's book, A Brief History of Time. Gail Vines (1997) once explained its success as follows: "Some say a science book can become a 'talisman'-a reassuring thing to have on the shelf at home, even if you can't understand it." In this respect, both the success of a quite sophisticated format and the emergence of a scientist personality cult are remarkable, but they are rare phenomena that may not be easily transferred to the times after Covid-19.

\section{The Role of Classical, Social, and Fake Media}

The second major area on which Covid-19 puts a special emphasis is the distribution of roles between classical and social but also on fake media. In an international comparison, the trust in Germany's established media before the crisis can be considered quite high. Intensive debates about 'fake news' and hate comments had led to a loss of trust in social media a few years ago, as longitudinal research by the Mainz Media Trust Study (Mainzer Langzeitstudie Medienvertrauen, 2020) indicates. It will be interesting to see how coronavirus will have affected trust in journalism in the future. In any case, the use of traditional media during the crisis has increased dramatically. Many, even young users, seem to be returning to public television (AGF Videoforschung, 2020). Initial surveys indicate that $T V$ is used much more frequently to provide information about Covid-19 than, for example, social media channels (COSMO, 2020). Similarly, many newspapers and magazines report an all-time high of hits on their online pages and a strong rise in the number of digital subscriptions. Again, it remains to be seen whether this trend will continue when the crisis has passed by (or already when people are no longer encouraged to stay at home).

Another question is the quality of reporting on Covid-19. While national daily and weekly newspapers, science editors and especially the journalistic Science Media Center Germany predominantly receive a positive evaluation, communication scholars have criticised television coverage as a "special form of court reporting" (Jarren, 2020). Too often the same experts would have been asked, mainly a handful of virologists, while other disciplines such as social and political scientists, psychologists, or ethicists would have been underrepresented. Other points of criticism concern well-known deficits of journalism: the handling of numbers and statistics (here, for example, of affected people) or the concentration on individual cases (e.g., Meier \& Wyss, 2020; for a summary of the criticism see Russ-Mohl, 2020).

The observation that, initially, the side effects of measures against the pandemic were not sufficiently addressed by asking also enough (non-virologist) experts is correct, but this has changed in the course of reporting. As far as the variety of virologists who have their say is concerned, it must be noted that corona viruses are not a common field of research. The choice of experts is therefore limited and as all media wanted to talk them, it automatically led to a shortage of experts. However, the criticism that there had been too much 'announcement journalism' may also be justified.

The criticism by academics is in turn criticized by journalists as too sweeping and without considering the extreme working conditions for journalists these days. 
Another problem with the communication scientists' criticisms of the classical media is that they receive much applause from the wrong side, having been misused in many fake news articles as 'proof' of conspiracy theories against the 'mainstream' media.

It is not yet possible to say what impacts fake news in the 'alternative' media has on public opinion about the pandemic. In a preliminary study, researchers from Muenster and Munich (Boberg, Quandt, Schatto-Eckrodt, \& Frischlich, 2020) established a computational content analysis of a corona-related sample consisting of 2,446 alternative, 18,051 mainstream, and 282 fact-checking posts. One of the results was:

Alternative news media stay true to message patterns and ideological foundations identified in prior research. While they do not spread obvious lies, they are predominantly sharing overly critical, even antisystemic messages, opposing the view of the mainstream news media and the political establishment. (Boberg et al., 2020, p. 1)

Furthermore, the "majority of posts mirrored traditional mainstream media reports in terms of their topical structure and the actors involved" (Boberg et al., 2020, p. 17). The authors conclude that the observed information mix (or "pandemic populism"; Boberg et al., 2020, p. 17) with a recontextualization into an anti-systemic metanarrative is much more likely to contribute to the feared 'infodemic' than simple lies. For media users, such a mix is much more difficult to unmask than just highly noncredible disinformation bits. More recently, there is also some evidence that conspiracy theories have received much more attention since late April/early May.

Such results speak in favour of the need of the investigation skills of professional journalism to navigate media users through the observed mix of truths, halftruths, and lies. However, this highlights a paradoxical situation: On the one hand, as also the media data underline, the demand for reliable information from serious news media is growing in the corona crisis, but on the other, these established, often privately financed media are now suffering severe economic losses (Meier \& Wyss, 2020). As already mentioned, publishers are reporting advertising declines of $80 \%$, and many have announced short-time working. The same virus that has once again increased the demand for their product could also herald their final end.

\section{Conclusion: Five Theses}

1. The corona crisis underlines the necessity of a reform of science communication of research institutions. Instead of primarily promoting the reputation of their own institution, the press and PR work must be strongly committed to the information about science-which would also create capacities to support extremely busy scientists with honest communication even in times of crisis. This may require new forms of organisation for $P R$ work in these institutions. Furthermore, in the communication of complex topics, different scientific disciplines must be considered simultaneously.

2. The success of individual formats in the corona crisis bears the temptation for television and radio to build up a new cult of stars around individual researchersand to offer them a stage that is hardly ever accompanied by journalism. However, more TV professors as solo entertainers and cheap content producers are not a solution for keeping the public informed. Competently selected scholars from a wide range of disciplines are important discussion partners in journalistic media. But they need informed and critically inquiring journalists as counterparts. This especially applies to government scientists, who must not be accompanied by mere announcement journalism.

3. Future media criticism should be more solutionoriented. In Germany, the fierce and only partially justified media criticism by academics was apparently understood by some journalists as know-it-all behaviour of securely paid professors towards a profession under extreme conditions and, financially, sometimes with its back to the wall. One way forward for academics could be to provide the editors with assistance in such cases (e.g., direct help in dealing with statistics) rather than simply analysing the deficits. In analogy to 'constructive journalism' a more 'constructive media criticism' should emerge to clearly support the role of journalism in a democracy, not to be misused as a key witness for alternative fake media.

4. The corona crisis has once again demonstrated how urgent it is for the general population to receive more training in media and source competence in schools and further education. The susceptibility of many people to targeted misinformation can be as risky as susceptibility to an aggressive virus. However, the kind of 'misinformation mix' observed has shown that many sources can often only be unmasked by professionals.

5. The corona crisis has shown the need for professional journalistic sources just as clearly as it has affected many of these sources in its business models. Reliable journalism, however, is as relevant as science or the health system. A support for journalism in the future is inevitable, and tax money can flow into it if the independency of the reporting is ensured. To this end, the money could be allocated directly to authors on the basis of peer review by journalists, following the model of research funding. Such grant procedures have already been established in the midst of the crisis: In April, the German Association of Science Journalists, for example, launched a donation-financed funding initiative which, following a peer review process, promotes investigations around the pandemic. Such initiatives should be continued and expanded.

In summary, the Covid-19 pandemic has immediate effects on the media and communication system, which in a few cases are atypical and likely to disappear again 
after the crisis. However, there is some evidence that the crisis has, above all, accelerated and made more visible developments and deficits that existed before. A sevenyear-old quotation from Martin Bauer (2013) illustrates that not everything observed above is new: "When independent science journalism is most needed, its economic basis is eroding." In the era of corona and its aftermath, this statement is truer than ever.

\section{Conflict of Interests}

The author declares no conflict of interests. However, he is member of the jury of the Communicator Award of the German Science Foundation as well as of the German Association of Science Journalists, both mentioned in the commentary.

\section{References}

acatech - National Academy of Science and Engineering, German National Academy of Sciences Leopoldina, \& Union of the German Academies of Sciences and Humanities (Eds.). (2017). Social media and digital science communication: Analysis and recommendations for dealing with chances and risks in a democracy. Munich: acatech - National Academy of Science and Engineering, German National Academy of Sciences Leopoldina, and Union of the German Academies of Sciences and Humanities. Retrieved from www.acatech.de/wp-content/uploads/ 2018/03/WOM2_EN_web_final.pdf

AGF Videoforschung (2020, April 8). AGF-Analyse zum Corona-Effekt: Jüngere Zielgruppen kehren ins TV zurück [AGF-analysis of the corona effect: Younger target groups are returning to TV] [Press release]. Retrieved from www.agf.de/agf/presse/ pressemitteilungen/?name=pm_20200408

Bauer, M. W. (2013). The knowledge society favours science communication, but puts science journalism into the clinch. In P. Baranger \& B. Schiele (Eds.), Science communication today. International perspectives, issues and strategies (pp. 145-166). Paris: CNRS Éditions.

Boberg, S., Quandt, T., Schatto-Eckrodt, T., \& Frischlich, L. (2020). Pandemic populism: Facebook pages of alternative news media and the corona crisis-A computational content analysis (Muenster Online Research Working Paper 1/2020 [Pre-print]). Muenster: University of Muenster. Retrieved from https://arxiv. org/abs/2004.02566

Connolly, K. (2020, March 31). Worst-hit German district to become coronavirus 'laboratory.' The Guardian. Retrieved from www.theguardian.com/world/2020/ mar/31/virologists-to-turn-germany-worst-hitdistrict-into-coronavirus-laboratory

COSMO (2020). COVID-19 snapshot monitoring (COSMO). Universität Erfurt. Retrieved from https:// projekte.uni-erfurt.de/cosmo2020/cosmo-analysis. html\#6_informationsverhalten

Jarren, O. (2020, March 27). Im Krisenmodus. Das öffentlich-rechtliche Fernsehen in Zeiten von Corona [In crisis mode. Public television in times of Corona]. Evangelischer Pressedienst. Retrieved from www.epd.de/fachdienst/epd-medien/schwerpunkt/ debatte/im-krisenmodus

Mainzer Langzeitstudie Medienvertrauen. (2020). Mainzer Langzeitstudie Medienvertrauen [Mainz long-term study media trust]. Johannes GutenbergUniversität Mainz. Retrieved from https:// medienvertrauen.uni-mainz.de

Meier, K., \& Wyss, V. (2020, April 9). Journalismus in der Krise: die fünf Defizite der Corona-Berichterstattung [Journalism in crisis: The five deficits of corona reporting]. Meedia. Retrieved from https://meedia.de/ 2020/04/09/journalismus-in-der-krise-die-fuenfdefizite-der-corona-berichterstattung

Rensberger, B. (2009). Science journalism: Too close for comfort. Nature, 459(7250), 1055-1056.

Russ-Mohl, S. (2012). Opfer der Medienkonvergenz? Wissenschaftskommunikation und Wissenschaftsjournalismus im Internetzeitalter [Victims of media convergence? Science communication and science journalism in the internet age]. In S. Füssel (Ed.), Medienkonvergenz transdisziplinär [Media convergence transdisciplinary] (pp. 81-108). Berlin: De Gruyter.

Russ-Mohl, S. (2020). Corona in der Medienberichterstattung und in der Medienforschung. Ein Dossier [Corona in media coverage and media research. A dossier]. Retrieved from https://de.ejo-online.eu/ wp-content/uploads/Corona-in-der-Medienbericht erstattung-und-Medienforschung.pdf ; update available at https://de.ejo-online.eu/qualitaet-ethik/ kritik-an-der-medienkritik-und-neue-kritik

Vines, G. (1997). Review: The cheque's in the post. New Scientist. Retrieved from www.newscientist.com/ article/mg15520927-000-review-the-cheques-inthe-post/\#ixzz6LCEh3W4Z

\section{About the Author}

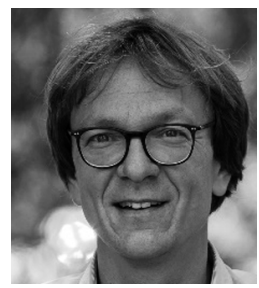

Holger Wormer is an ordinary Professor and Director of the Institute of Journalism at TU Dortmund University where he has established the first consecutive Bachelor and Master courses in Science Journalism at a German University. Before that he worked as a journalist for many years, including eight years as science editor for the national newspaper Süddeutsche Zeitung. Since 2012, he has also been member and later Co-Speaker in three expert groups of the German Academies of Sciences dealing with the future of science communication. 